\title{
RESEARCH OF ANTIGEN AND ANTIBODIES FROM RETROVIRUSES, CMV AND HBV AMONG PRISONERS OF THE PENITENTIARY COMPLEX OF THE REGION OF CAMPINAS, SP, BRAZIL
}

\author{
Neusa Maria OSTI (1), Antonio Fernando PESTANA DE CASTRO(2) \& Lucila COSTALLAT RICCI (2)
}

\section{SUMMARY}

Some viruses of the families Retroviridae, such as Human T Lymphotropic Virus (HTLV); Herpesviridae as the Cytomegalovirus (CMV) and Hepadnaviridae such as the Hepatitis B Virus (HBV) are liable to be co-transmitted with the Human Immunodeficiency Virus (HIV). Since prisoners are exposed to several and important risk factors involved in the transmission of HIV and the above mentioned viruses, male inmates from the penitentiary complex of Campinas, SP, Brazil, including HIV + and HIV - ones, were examined for the presence of HTLV-I and/or II antibodies; IgG and IgM anti-CMV antibodies, and the research of the superficial hepatitis B antigen (HBsAg). The presence of anti-HTLV-I and/or II was determined by the Western Blot (WB) technique, whereas IgG and IgM anti-CMV and the search of HBsAg were carried out by the Microparticle Enzyme Immunoassay (MEIA-Abbott Lab).With regard to anti-HTLV-I and/or II, 58.3\% (14/24-Number of positive reactions/number of sera examined) were reactive among the anti-HIV positive sera. Conversely, only $12.5 \%$ (3/24) among the HIV- negative sera showed positive reactions to HTLV-I and/or II antibodies. When looking for IgG anti-CMV percentages of $97.7 \%(43 / 44)$ and $95 \%$ (38/40) were obtained for anti-HIV positive and negative sera, respectively. As to IgM anti-CMV antibodies $11.36 \%(5 / 44)$ and $2.5 \%(1 / 40)$ of reactive sera were found for anti-HIV positive and negative, respectively. The HBsAg was found in $12.8 \%(5 / 39)$ of the sera which were anti-HIV positive.

KEYWORDS: AIDS; Prisoners; Co-transmission; HBV; CMV; HTLV

\section{INTRODUCTION}

In preliminary studies, working with male prisoners from three penitentiaries in the region of Campinas SP, Brazil, of which two (A and B) were considered as with maximum security system and another (C) as a Detention Center or minimal security facility we have found that among 693 inmates $100(14.43 \%)$ were positive for anti-HIV antibodies when using the Microparticle Enzyme Immunoassay-HIV1 and HIV-2 (MEIA-Abbott Laboratories) and the Western BlotHIV-1 (Cambridge Biotech. Corporation), as a confirmatory test. (submitted).

There are strong evidences that HBV, HTLV-1 and/or II as well as CMV may be transmitted to susceptible individuals by the same routes by which the HIV infects human being ${ }^{9,12,20,25}$. These included mainly sexual ${ }^{14,18,25}$, blood transfusion and drug addiction ${ }^{14,16,18,23,29}$. Based upon these facts and taking into consideration the many risk factors to which male prisoners are exposed $d^{2,4.5}$ such as spontaneous or forced sexual activities among homosexuals, heterosexual intercourse with visitors, time and type of imprisonment, possibility of using intravenous injection drugs and wounds caused by stabbing with HIV-infected knives during uprisings, one may assume that the co-transmission of HIV and
HTLV-I and/or II, HBV and CMV should occur among prisoners maintained in conditions which favored the above risk factors. Therefore, it is conceivable to assume that if co-transmission of HIV and some or all the above viruses mainly HTLV-II ${ }^{6}$ does occur the picture and evolution of AIDS among prisoners could be worse than in the general population although there is much controversy in this particular field ${ }^{3,13,19,21}$.

\section{OBJECTIVES}

The present study was undertake in order to find out whether among prisoners from maximum and minimal systems of the penitentiary complex of the region of Campinas, SP, Brazil, on account of the many risk factors that they are submitted to, cotransmission of HIV, HTLV-1, HBV and CMV might occur as sustained by the frequencies of double or multiple infections by these viruses.

\section{MATERIALS AND METHODS}

Sera collection. Sera samples from prisoners HIV+ and HIVwere collected from January to August, 1995, using for this

(1) Department of Clinical and Toxicological Analysis, College of Medical Sciences, Catholic University of Campinas (PUCAMPP) Campinas, SP, Brazil

(2) Department of Microbiology and Immunology, Institute of Biology, University of Campinas (UNICAMP), Campinas, SP, Brazil.

Correspondence to: Prof. A. F. Pestana de Castro, Institute of Biology, Department of Microbiology and Immunology, University of Campinas, 13083-970- Campinas, SP, Brazil. 
OSTI, N.M.; PESTANA DE CASTRO, A.F. \& RICCI, L.C. - Research of antigen and antibodies from retroviruses, CMV and HBV among prisoners of the penitentiary complex of the region of Campinas, SP, Brazil. Rev. Inst. Med. trop. S. Paulo, 40 (4): 209-213, 1998.

purpose $10 \mathrm{ml}$ vacuum container vials, labeled with the full names of the individuals taking care to avoid any contamination of the lab and devices, following CDC, level 2 recommendations for processing blood and other human specimens contaminated by HIV $10,11,12$.

Samples processing and tests. After clotting,the samples of blood were centrifuged at 3,000 rpm for $10 \mathrm{~min}$ and the sera were carefully transferred to Khan's tubes, with appropriate caps and the respective identification of each one. When sera were not examined on the same day, the tubes were stored at $-25^{\circ} \mathrm{C}$, up to testing.

Test for searching antibodies against HTLV. A total number of 48 sera, being 24 HIV + and 24 HIV- were examined. A qualitative Western Blot (WB) assay (Cambridge Biotech Corporation ) for the detection of antibodies against antigens from HTLV-1/II was used. The reagents, instructions for their preparation, and procedures for carrying out the assay followed the recommendations of the manufactures. Readings of the results were also performed according to instructions. Briefly, samples of sera were considered positive for HTLV-I/II when the band P24 and gp 46 or $\mathrm{p} 21$ env were present, showing intensity grade $\geq 1$. The negative sera were identified by absence of any specific band. The identification of sera with indeterminate profile types I and II were done as described by FERREIRA et al. ${ }^{17}$.

Tests for searching IgG and IgM antibodies against cytomegalovirus (CMV). Eighty-four sera collected from prisoners, being $44 \mathrm{HIV}+$ and $40 \mathrm{HIV}$-, were screened for CMV antibodies. The Microparticle Enzyme Immunoassay (MEIA), $3^{\text {rd }}$ generation (Abbott Laboratories, Illinois, U.S.A.) was used. To

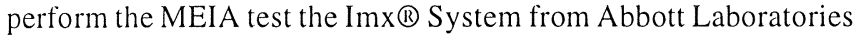
was used, following all the instructions of the manufacturers for both types of tests, that is, IgG and IgM anti-CMV antibodies. Sera positive for IgG anti-CMV were considered positive when the readings gave results $\geq 15$ antibody units(AU) and negative when less than this value. According to the instructions of the manufacturers, sera were positive for IgM anti-CMV when the ratio of the reading of the sample over the reading of the calibrator (index) was $\geq 0,500$ and negative when this ratio was less than 0,500 .

Test for searching the HBS antigen ( HBsAg). Sera from 39 HIV+ inmates and $30 \mathrm{HIV}$ - ones were sampled for the search of HBsAg. For this purpose the MEIA test (Abbott Laboratories, Illinois, U.S.A.) was also used as well as the Imx® System from the same source. The preparations of the reagents, respective procedures for the test, and readings were performed according to instructions of the manufacturers. Briefly, the results were considered positive for the $\mathrm{HBsAg}$ when the ratio of the reading of the sample of serum under test over the reading of the calibrator (index) was $\geq 2,000$ and negative when this value was less than 2,000 .

Statistical analysis. All results were statistically evaluated by the EpiInfo version 6.0, from October, 1994, developed by the CDC, Atlanta Georgia, U.S.A .

\section{RESULTS}

The results of the WB tests carried out for the presence of HTLV-I/II antibodies among 48 sera from prisoners of the penitentiary complex of the region of Campinas, SP, Brazil, are shown in Table 1. Among the HIV+ sera 14 (58.3\%) were positive for HTLV-I/II antibodies. Among the HIV- only 3 (12.5\%) were positive. The number of indeterminate reactions (type 2 only) was high in both groups. Following the procedures recommended by FERREIRA et al. ${ }^{17}$ the individuals with indeterminate reactions were apparently healthy after 16 months, when their sera were examined again. Most of them showed in the retest negative results and a few remained with indeterminate reactions type 2 (data not shown). For this reason in the statistical analysis the sum of negative and indeterminate reactions was taken.

The results of the MEIA test for searching IgG and IgM antibodies against CMV among 84 samples of sera from prisoners are shown in Table 2. As recommended by the manufacturers of the kit used for this test, all sera with positive results for CMV- IgM

TABLE 1

Antibodies against HTLV-I and/or II among sera from prisoners of the Penitentiary Complex of the region of Campinas, SP, Brazil, detected by the Western Blot (WB) technique.

\begin{tabular}{lcccc}
\hline \multirow{2}{*}{ Prisoners' sera } & \multicolumn{4}{c}{ Anti-HTLV-I and/or II Antibodies } \\
\cline { 2 - 5 } & nesults \\
\cline { 2 - 5 } & number of & & \\
& sera examined & Positive & Negative & Indeterm. $^{1}$ \\
\cline { 2 - 5 } HIV- positive & 24 & $(\mathrm{P})$ & $(\mathrm{N})$ & $(\mathrm{I})$ \\
HIV- negative & 24 & 14 & 0 & 10 \\
\hline
\end{tabular}

' Only type 2 indeterminate profile was found.

For $\mathrm{P} \times \mathrm{N}$, in the Fisher's Exact test, $\mathrm{p}=0.22222$ (NS)

For $\mathrm{P} \times \mathrm{N}+\mathrm{I}$, in the Fisher's Exact test, $\mathrm{p}=0.001114(\mathrm{~S})$ * 
OSTI, N.M.; PESTANA DE CASTRO, A.F. \& RICCI, L.C. - Research of antigen and antibodies from retroviruses, CMV and HBV among prisoners of the penitentiary complex of the region of Campinas, SP, Brazil. Rev. Inst. Med. trop. S. Paulo, 40 (4): 209-213, 1998.

TABLE 2

Results of the detection of anti-CMV by the MEIA test in HIV+ and HIV- sera of prisoners of the penitentiary complex of the region of Campinas, SP, Brazil

\begin{tabular}{lcccccc}
\hline & \multicolumn{5}{c}{ Anti-CMV antibodies } \\
\cline { 2 - 7 } & \multicolumn{3}{c}{$\operatorname{IgG}^{1}$} & Results & IgM $^{2}$ \\
\cline { 2 - 7 } & $\begin{array}{l}\text { Nb. of sera } \\
\text { examined }\end{array}$ & positive & negative & $\begin{array}{c}\text { Nb. of sera } \\
\text { examined }\end{array}$ & positive & negative \\
\hline HIV-positive & 44 & 43 & 01 & 44 & 05 & 39 \\
HIV-negative & 40 & 38 & 02 & 40 & 01 & 39 \\
\hline
\end{tabular}

' $p=0.60287$ (NS), by the Fisher's Exact Test. ${ }^{2} \mathrm{p}=0.20290$ (NS ), by the Fisher's Exact Test.

were tested with the neutralizing reagent for the rheumathoid factor. Thus, 22 initial positive reactions were reduced to only 6 , which means that 16 samples of sera were not true positive tests for antiCMV IgM antibodies (data not shown).

Thirty-nine HIV+ sera and 30 HIV - ones were examined for the presence of HBsAg, by the MEIA test, whose results are shown in Table 3. Among the former group of prisoners 5 showed positive reactions in this test, whereas all HIV-were also negative for the presence of $\mathrm{HBsAg}$.

\section{TABLE 3}

Results of the detection of HBsAg by the MEIA test in HIV+ and HIVsera from prisoners of the penitentiary complex of the region of Campinas,SP, Brazil

\begin{tabular}{lccc}
\hline & \multicolumn{3}{c}{ HBs Antigen( HBsAg) } \\
\cline { 2 - 4 } & Nb.of sera & \multicolumn{2}{c}{ Results } \\
\cline { 2 - 4 } & examined & Positive & Negative \\
\hline HIV- positive & 39 & 05 & 34 \\
HIV- negative & 30 & - & 30 \\
\hline
\end{tabular}

' $p=0.06391$ (NS ) by the Fisher's Exact Test, but with a tendency to significance since the value of $p>0.05$ and $<0.10$, but close to 0.05 .

\section{DISCUSSION}

The choice of working with prisoners is obvious because of the multifactorial risks to which those individuals are subjected, mainly taking into consideration the critical conditions of our penitentiaries. Unfortunately, as a consequence, a lot of information which should be desirable in a study such this one, could not be obtained. Some of them are pointed out: time of confinement not yet served, ethnic groups, and presence of initial symptoms of clinical AIDS (those with overt disease were always transferred to the penitentiary infirmary for further treating). Additional information such as, homosexual, bisexual and heterosexual behavior, characteristics and frequency of female partners we were unable to attain. Finally, though one might suspect, it was impossible to know how many had been and still were IVDUs. Overall, we assumed that prisoners were subjected to several risk factors which increase the possibility of HIV infection and considering its routes of transmission, linked to the above mentioned situations, it was thought to be advisable to look in prisoners' sera for parameters which could indicate infection by other viruses such as HTLV-I/II, CMV and HBV as it has been shown by other authors in studies carried out with prisoners ${ }^{9}$, IVDUs ${ }^{6,7,8,27,28}$ in blood transfusions ${ }^{1}$ and among individuals and other risk factors, involving mainly sexual behavior ${ }^{30}$.

Our studies demonstrated that among 24 samples of HIV+ sera, $14(58.3 \%)$ were also positive for HTLV-I/II antibodies. Conversely, among the HIV- ones only three (12.5\%) were positive, being high the number of indeterminate reactions (type II only) in both groups. If we compare our results with those reported before with other groups of Brazilian prisoners ${ }^{24}$ it is observed that among 93 inmates, from a small prison system in the interior of the State of São Paulo, Brazil, ${ }^{24}$ (7.5\%) were HIV+, but no reactions for HTLV-I/II were observed. In this same research, working with 41 prisoners of the Main Penitentiary System of the City of São Paulo, SP, Brazil, who showed typical symptoms of AIDS, only one (2.4\%) HTLV+ reaction was observed. This latter study was carried out in 1992 and since then the methods for the detection of HTLV infection have improved, fact that might explain the mentioned differences among their results and ours. Another research in our country with blood donors ${ }^{17}$, including 17,063 persons revealed that 29 $(0.16 \%)$ were positive for HTLV-I. Also it was reported in this study that $104(0.60 \%)$ individuals showed indeterminate (type 2) reactions, a result which fits better with ours. In this research the authors also considered indeterminate reactions type 2, as negative ones, since after repeated tests most of them became negative in the WB. Because this survey did not include reactions for HIV infection we cannot make comparisons between the correlation of HIV + or HIV- and HTLV sera.

The rates of cytomegalovirus(CMV) infection is very high among the general population, usually without any clinical symptom. These individuals behave as carriers of the virus, which is intermittently eliminated through the saliva, urine, semen, genital 
OSTI, N.M.; PESTANA DE CASTRO, A.F. \& RICCI, L.C. - Research of antigen and antibodies from retroviruses, CMV and HBV among prisoners of the penitentiary complex of the region of Campinas, SP, Brazil. Rev. Inst. Med. trop. S. Paulo, 40 (4): 209-213, 1998.

secretions and mother's milk. However, when AIDS is clinically apparent this virus often causes either serious ${ }^{22}$ or fatal disease ${ }^{15}$. Though we could assume that the co-transmission of HIV and CMV might occur ${ }^{15}$ rendering worse the cases of AIDS among the prisoners studied in this research, the MEIA test carried out for searching IgG and IgM antibodies among the HIV+ and HIVindividuals showed no significant $(\mathrm{p}=0.60287$ for $\operatorname{IgG}$ and 0.20290 for IgM) (table 2) correlation. Probably this has occurred on account of the high frequency of CMV infection in adults, either prisoners or not, has it has been shown by the results that we found among the control population (data not shown).

The result of the studies of the correlation of HIV + and HIVsera with the presence of $\mathrm{HBsAg}$ showed that 05 (12.82\%) prisoners HIV + were also reactive for HBV whereas none of the HIV-were positive for HBV. The Fisher's exact test showed a $\mathrm{p}=$ 0.06391 (NS) but with a tendency to significance by the fact that the p value was between $5 \%$ and $10 \%$, very close to the former. A previous research in our country ${ }^{24}$, including prisoners from a small prison (a) in the interior of the State of São Paulo, and inmates from the Main Penitentiary System (b) of the City of São Paulo, SP, showed a high correlation of HIV infection and positive reactions for $\mathrm{HBsAg}$ for both ( $\mathrm{a}$ and $\mathrm{b}$ ). These data support ours in spite of the fact that no statistical analysis was carried out in that research. Another very important comment is related to the fact that we could not perform tests to detect $\mathrm{HBc}$ and $\mathrm{HBsAg}$ antibodies as well as $\mathrm{HBe}$ antigen. A similar research carried out in Spain ${ }^{7}$ revealed that the correlation between HIV+ sera and the presence of $\mathrm{HBsAg}$, among prisoners was around $11.1 \%$, very close to that found in our work. When only one additional diagnostic marker was used the percentage of positivity increase to $15.5 \%$. In other words, based upon those data we can guess that if we had used the above mentioned tests, which we were unable to carry out, the frequency of HBV infection would be higher, probably within the significance levels when comparing HIV and HBV. In addition, very recently in a cohort study in Turin, Italy ${ }^{26}$, it was found that seroconversion to HBV and HIV was associated with IVDUs.

In conclusion, because of the risk factors that prisoners are submitted to in Brazilian penitentiaries, the concomitant infections by HIV and other viruses, such as HTLV and HBV is a serious reality to be considered by the Public Health authorities.

\section{RESUMO}

\section{Pesquisa de antígenos e anticorpos de retrovírus, CMV e HBV entre prisioneiros do complexo Penitenciário de Campinas, SP, Brasil.}

Alguns vírus das famílias Retroviridae, tais como, o Vírus do Linfoma Humano de Células T ( HTLV); Herpesviridae, tais como o Vírus Citomegálico (CMV) e da Hepatite B (HBV) podem ser co-transmitidos com o Vírus da Imunodeficiência Adquirida (HIV). Uma vez que prisioneiros estão expostos a diversos fatores de risco envolvidos na transmissão do HIV e dos vírus acima mencionados, prisioneiros do sexo masculino do Complexo Penitenciário de Campinas, SP, Brasil, incluindo aqueles que eram HIV+ e HIV-, foram examinados para a presença de anticorpos anti- HTLV-I/II; anticorpos IgG e IgM anti-vírus citomegálico e a presença do antígeno de superfície do HBV (HbsAg). A presença de antiHTLV-I/II foi determinada pela técnica de Western Blot, enquanto IgG e IgM anti-CMV e a pesquisa do HbsAg foram feitas por ensaio Imunoenzimático (MEIA-Abbott Lab). Com relação à pesquisa de anti-HTLV-I/II, 58,3\% (14/24- número de positivos/ número total de soros examinados) foram reagentes entre os soros HIV+. Contrariamente, apenas $12,5 \%$ (3/24) entre os soros HIVmostraram reações positivas para anti- HTLV-I/II. Porcentagens de $97,7 \%$ (43/44) e $95 \%$ (38/40) foram obtidas, respectivamente para os soros anti-HIV+e anti-HIV-, em relação à pesquisa de IgG anti-CMV. No que concerne à IgM anti-CMV 11,36\% (5/44) e 2,5\% (1/40) foram os achados para os soros anti-HIV+ e anti-HIV-, respectivamente. A presença do $\mathrm{Hbs} \mathrm{Ag}$ foi encontrada em $12,8 \%$ (5/39) dos soros que eram HIV+.

\section{ACKNOWLEDGEMENTS}

This research was supported by grants from the "Serviço Unificado de Saúde" (SUS), from the Brazilian Ministry of Health, "Fundação de Amparo à Pesquisa do Estado de São Paulo (FAPESP) and by "Conselho Nacional de Desenvolvimento Científico e Tecnológico (CNPq) from Brazil.

\section{REFERENCES}

1. AL-MAhroOS, F. T. \& EBRAhIM, A. - Prevalence of hepatitis B, hepatitis $\mathrm{C}$ and human immunodeficiency virus markers among patients with hereditary haemolytic anaemias. Ann. trop. Paediat., 15 :121-128, 1995.

2. BENEZECH, M.; RAGER, P. \& BEYLOT, J. - AIDS and hepatitis B in the prison population: an unavoidable epidemiologic reality. Bull. Acad. nat. Méd. (Paris), 171: 215-218, 1987.

3. BESSINGER, R.; BEILKE M.; KISSINGER P.; JARROT, C. \& TABAK, O.F.Retroviral coinfections at a New Orleans HIV outpatient clinic. J. Acquir. Immune Defic. Syndr. hum. Retrovirol., 14: 67-71, 1997.

4. BIRD, A. G.; GORE, S.M.; CAMERON, S.; ROSS, A.J. \& GOLDBERG, D. J. - Anonymous HIV surveillance with risk factor elicitation at Scotland's largest prison, Barlinnie. AIDS ( Philadelphia ), 9: 801-808, 1995.

5. BOWELL, S. L.- Pathophysiology and natural history. In: LIBMAN, H. \& WITZBURG, R. A. HIV infection: a primary care manual. 3. ed. Boston, Little, Brown \& Company, 1996. p. 3-17.

6. BRIGSS, N. C.; BATTYES R. J.; CANTOR K.P.E. et al.- Seroprevalence of human $\mathrm{T}$ cell lymphotropic virus type II infection, with or without human immunodeficiency virus type 1 coinfection, among US intravenous drug users. J. infect. Dis., 72: 55-58, 1995.

7. CARBAJAL, C.L.; VALLINA, E.; ARRIBAS, J.M.; DIAZ, J. \& DOMINGUES B.- Epidemiological study of prisoners at risk for AIDS in a Spanish prison. Ann. Med. Intern., 8: 382-386, 1991.

8. CARVAlHO, H. B. D.; MESQUITA, F.; MASSAD, E. et al. - HIV and infections of similar transmission patterns in a drug injectors community of Santos, Brazil. J. Acquir. Immune Defic. Syndr. hum. Retrovirol., 12: 84-92, 1996. 
OSTI, N.M.; PESTANA DE CASTRO, A.F. \& RICCI, L.C. - Research of antigen and antibodies from retroviruses, CMV and HBV among prisoners of the penitentiary complex of the region of Campinas, SP, Brazil. Rev. Inst. Med. trop. S. Paulo, 40 (4): 209-213, 1998.

9. CATTANEO, C.; NUTTALL, P.A. \& SOKOL, R.J. - Detection of HIV, hepatitis $\mathrm{B}$ and hepatitis $\mathrm{C}$ markers in discarded syringes and bloodstains. Sci. \& Justice, 36: 271-274, 1996

10. CENTERS FOR DISEASE CONTROL - Recommendations for preventing transmission of infection with human T- lymphotropic virus type III lymphadenopathy-associated virus in the workplace. M.M.W.R., 34: 682695,1985

11. CENTERS FOR DISEASE CONTROL - Recommendations for prevention of HIV transmission in health-care settings. M.M.W.R., 36: 1S-18S, 1987.

12. CENTERS FOR DISEASE CONTROL - Update: universal precautions for prevention of transmission of human immunodeficiency virus, hepatitis $B$ virus and other blood pathogens in health-care settings. M.M.W.R., 37: $377-378,1988$

13. CHAVANCE, M.; NEISSON-VERNANT, C.; QUIST, D. et al. - HIV/HTLV-I coinfection and clinical grade at diagnosis. J. Acquir. Immune Defic. Syndr. hum. Retrovirol., 8: 91-95, 1995.

14. COPPOLA, R.C.; MASIA, G.; MARTINO, M.L.D. et al. - Sexual behaviour and multiple infections in drug abusers. Europ. J. Epidem., 12: 429-435, 1996.

15. DREW, W.L. - Cytomegalovirus infection in patients with AIDS. J. infect. Dis., 158: 449-456, 1988.

16. DUFOUR, A.; ALARY, M.; POULIN, C. et al. - Prevalence and risk behaviour for HIV infection among inmates of a provincial prison in Quebec city. AIDS, 10: 1009-1015, 1996.

17. FERREIRA JR., O.C.; VAZ, R.S.; CAMARGO, M.B. et al. - Human Tlymphotropic virus type I and type II infections and correlation with risk factors in blood donors from São Paulo, Brazil. Transfusion, 35: 258-263, 1995

18. GARFEIDN, R.S.; VLAHOV, D.; GALAI, N.; DOHERTY, M.C. \& NELSON, K.E. - Viral infections in short-term injection drug users: the prevalence of hepatitis $C$, hepatitis $B$, human immunodeficiency and human $T$ lymphotropic viruses. Amer. J. publ. Hlth., 86: 655-661, 1996.

19. HERSHOW, R.C.: GALAI, N.; FUKUDA, K. et al. - An international collaborative study of the effects of coinfection with human T-lymphotropic virus type II on human immunodeficiency virus type 1 disease progression in injection drugs users. J. infect. Dis., 174: 309-317, 1996
20. KAPLAN, J.E. \& KHABBAZ, R.F. - The epidemiology of human Tlymphotropic virus types I and II. Rev. Med. Virol., 3: 137-148, 1993.

21. MAGNANI, G., FRANCO, E.G.; CLAUdiO, C. et al. - Human T-leukemia virus type II infection among high risk groups and its influence on HIV-1 disease progression. Europ. J. Epidem., 11: 527-533, 1995.

22. PERTEL, P.; HIRSCHTICK, R.; PHAIR, J. et al. - Risk of developing cytomegalovirus retinitis in persons infected with human immunodeficiency virus. J. Acquir. Immune Defic. Synd. Retr., 5: 1069-1074, 1992.

23. RHODES, T.; HUNTER, G. M.; STIMSON, G.V. et al. - Prevalence of markers for hepatitis B virus and HIV-1 among drug injectors in London: injecting careers, positivity and risk behaviour. Addiction, 91: 1457-1467, 1996.

24. SCHECHTMANN, M.; NEITZER, E.; SOUZA, L.N.X. et al. - AIDS entre presidiários brasileiros: considerações sobre o possível papel do virus HTLV e HBV como co-fatores implicados na patogênese da AIDS. Rev. bras. Med., 50: 488-496, 1993.

25. SCHOCHETMAN, G. - Biology of human immunodeficiency viruses. In: SCHOCHETMAN, G. \& GEORGE, J.R. AIDS testing. 2.ed. New York, Springer Verlag, 1994. p. 15-31.

26. SINICCO, A.; FORA, R.; SCIANDRA, M. \& RATIERI, R. - Seroconversion to $\mathrm{HBV}$ associated with seroconversion to HIV in a cohort of intravenous drug misuser in Turin, Italy. Europ. J. Epidem., 11: 535-539, 1995.

27. STARK, K.; SCHEIER, E.; MUELLER, R. et al. - Prevalence and determinants of anti-HCV seropositivity and of HCV genotype among intravenous drugs users in Berlin. Scand. J. infect. Dis., 27: 331-337, 1995.

28. STARK, K.; MUELLER, R.; BIENZLE, U. \& GUGGENMOOS-HOLZMANN, I. - Frontloading: a risk factor for HIV and Hepatitis $\mathrm{C}$ virus infection among injecting drug users in Berlin. AIDS, 10:311-317, 1996

29. White, D.O. \& FENNER, F.J. - Medical virology. 4. ed. San Diego, Academic Press, 1994.

30. ZAPIOLA, I.; SALOMONE, S.; ALVAREZ, A. et al. - HIV-1, HIV-2, HTLVI/II and STD among female prostitutes in Buenos Aires, Argentina. Europ. J. Epidem., 12: 27-31, 1996.

Received: 17 March 1998

Accepted: 09 June 1998 